\title{
Pre-service Teacher Subjective Responsibility for Pupil Outcomes: Pilot Study
}

\section{Veronika Pečivová}

\begin{abstract}
Although teacher responsibility is a rather frequently investigated topic, less attention has been paid to teacher personal perception of responsibility for pupil outcomes. This study presents results of a pilot quantitative questionnaire investigation of pre-service primary teachers at a Czech university with the aim to reveal teacher trainees' approach to their subjective responsibility for pupil success or failure. The preliminary findings suggest that pre-service teachers tend to assume a greater responsibility for pupil success than for his or her failure. Since the results of our quantitative questionnaire research do not provide a more complex insight into pre-service teachers' perception of responsibility in a broader sense, the study sets goals for further mixed methods research combining longitudinal quantitative and qualitative strategies.
\end{abstract}

Key words: teacher responsibility, pupil success, pupil failure, pre-service teacher, pilot testing. 


\title{
Subjektivní odpovědnost studenta učitelství za žákovské výsledky: pilotní studie
}

\begin{abstract}
Abstrakt
Přestože je odpovědnost učitele tématem, kterým se výzkumná šetření zabývají poměrně často, méně pozornosti se věnuje tomu, jak učitel vnímá svou odpovědnost za výsledky žáků. Tato studie předkládá výsledky pilotního kvantitativního dotazníkového šetření u studentů učitelství pro 1. stupeň základní školy jedné české univerzity s cílem ukázat přístup studentů učitelství k jejich subjektivní odpovědnosti za žákovský úspěch či neúspěch. Výsledky předvýzkumu naznačují, že studenti učitelství mají tendenci připisovat si větší odpovědnost za žákův úspěch než za jeho neúspěch. Jelikož výsledky našeho kvantitativního dotazníkového šetření neposkytují komplexnější vhled do vnímání odpovědnosti u studentů učitelství v širším smyslu, text vymezuje také cíle pro budoucí smíšený výzkumu, který bude zahrnovat jak kvantitativní, tak kvalitativní longitudinální strategie.
\end{abstract}

Klíčová slova: odpovědnost učitele, žákovský úspěch, žákovský neúspěch, student učitelství, pilotní šetření.

\section{Introduction}

With growing pressure on schools concerning student achievement, many researchers have noted that teacher responsibilities present an important area of investigation. The context of responsibility is very broad and includes a wide range or areas. In their study, Helker, Wosnitza (2014) dealt with the responsibility frame within school context from the view of teachers, students and parents, who mutually influence each other and they defined up to 84 different goals of responsibility. Obviously, the concept of responsibility is very complex and may be viewed from many perspectives. While numerous studies dealing with school performance focus on teacher accountability ${ }^{1}$, less attention has been paid to teacher internal subjective responsibility.

The way teachers themselves perceive their influence on pupil outcomes can be approached from different, broader perspectives. Matteucci et al. (2017) discussed links between responsibility and teacher wellbeing. Their investigation demonstrated a correlation between subjective teacher responsibility and wellbeing. In other words, the more responsible for pupil results teachers felt, the stronger was their job satisfaction.

Pol (2007) perceives accountability in the context of changing situation of schools and views its purpose as a tool for supporting pupil learning and outcomes and also for maintaining trust of the public in school (Pol, 2007, p. 42). 
Some researchers have aimed to discover connections between self-efficacy and teacher responsibility. Lauermann, Karabenick (2013) concluded that teacher responsibility and self-efficacy are conceptually distinct and that although the two concepts are interrelated, the correlation depends on the type of learning outcome. Similar conclusions are supported by findings of other authors (Silverman, 2010, Matteucci, Kopp, 2013, Frumos, 2015).

Previous research has demonstrated that teachers tend to feel responsibility for pupil success but on the other hand, they put the blame for failure on pupils. This responsibility attribution tendency was closely analysed in earlier studies (Guskey, 1981, Mareš, Skalská, Kantorková, 1994, Dofková, Zdráhal, 2018).

Although considerable research has been devoted to teacher responsibility of in-service teachers, fewer researchers have focused on students of teacher training programs. In our research we concentrated particularly on this group. The aim of the investigation was to examine whether pre-service teachers attribute the cause for pupil success and failure to themselves or to the pupils. In this paper we present results of our pilot testing of primary school teacher trainees at a Czech university. In addition, the study reveals an outline of our future research.

\section{Subjective teacher responsibility}

The crucial concept of our research is subjective teacher responsibility, which is defined as teacher internal responsibility forming part of teacher's professional identity (Mareš, Skalská, Kantorková 1994). Other authors use terms self-responsibility (Guskey, 1981), teacher's perceived personal responsibility (Matteucci, Kop, 2013) or personal responsibility, which "reflects a sense of internal obligation and commitment to produce or prevent designated outcomes or that these outcomes should have been produced or prevented" (Lauermann, Karabenick, 2011, p. 127).

This internal aspect of the concept contrasts with external accountability: "Whereas those who are held responsible are judged as such externally, those who feel responsible act as their own judges of responsibility and hold themselves accountable, which implies internal regulation." (Lauermann, Karabenick, 2011, p. 123). Subjective responsibility is not imposed but comes from within, it is inherent and becomes part of an individual (Šatienè, 2017) and is related to teacher self-regulation, autonomy, self-concept and his or her professional consciousness (Lukášová, 2015). Inspecting and identifying one's subjective responsibility is a way of professional identity self-reflection and selfevaluation (Lukášová, 2017).

Subjective teacher responsibility is also related to teacher self-efficacy and there is a positive correlation between these two concepts (Gavora, 2008, Lauermann, Karabenick, 2011, 2013, Silverman, 2010, Mareš 2013, Matteucci, Kopp, 2013, Frumos, 2015). 
Regarding this connection, Gavora (2008) describes two self-efficacy approaches: locus of control of Julian Rotter (1966, In Gavora, 2008) and the socio-cognitive learning theory of Albert Bandura (1991, 1994, In Gavora, 2008). Based on Rotter's concept, teachers may be divided into two categories: 1 ) teachers who attribute causes of student's successful learning to themselves and 2) teachers who attribute causes for successful results to students and other external factors. In terms of socio-cognitive learning theory, two concepts are mentioned: personal teaching efficacy and general teaching efficacy. The former reflects teacher's belief in his or her ability to influence student's learning and behavior and the latter reflects teachers' attribution of success in class to themselves or to external factors (Gavora, 2008).

Although our research does not view subjective responsibility within a broader context we believe it is necessary to introduce the concept from different perspectives. Questionnaire of subjective responsibility used in our survey provides a self-reflective tool, which may help pre-service teachers better understand certain aspects their professional identity.

\section{Methodology of Research}

The data of our pilot testing were collected from primary school pre-service teachers at a Czech university. Participants were recruited in two lectures which they attended in their primary school education program. Overall, 54 students completed the survey 39 respondents were in the first year and 15 in the second year of their studies. However, two questionnaires were excluded from the survey data due to invalid answers.

The respondents were invited to complete a quantitative research questionnaire (Questionnaire of pre-service teacher responsibility for pupil outcome, Mareš, Kantorková, 1991, In Lukášová-Kantorková, 2003 - given in Annex 1), which is a standardised version of a scale RSA questionnaire (Responsibility for Student Achievement) developed by Guskey (1981). The RSA questionnaire includes 30 items designed to present an educational situation describing a positive or a negative student achievement. The respondents are to divide 100 percentage points between two given options reflecting their view of responsibility attribution.

On the other hand, the pre-service teacher responsibility questionnaire (Mareš, Kantorková, 1991, In Lukášová-Kantorková, 2003) is composed of 20 items offering two alternatives (see Annex 1). All the items represent situations dealing with a class as a whole and lead to reflections on influences of pupil outcomes (Mareš, Skalská, Kantorková, 1994, p. 26). Ten items are related to pupil success and the other half focuses on pupil failure and each of them provides two possible causes - one option attributes subjective responsibility for pupil positive or negative result to the teacher and the other option to the pupil. Due to the preliminary character of our research we 
instructed the respondents to choose one of the statements attributing cause of the pupil result either to the teacher or to the pupil instead of dividing 100 percentage points between them.

In our research, following research questions were answered:

1. Who do pre-service primary teachers attribute causes of pupil success in class to?

2. Who do pre-service primary teachers attribute causes of pupil failure in class to?

For the data analysis, we used descriptive statistics, i.e. absolute and relative frequencies in the program Microsoft Excel.

\section{Results and discussion}

In the data analysis the results for pupil success and pupil failure are presented separately. The bar graphs show results for each questionnaire item, 10 of which relate to a positive outcome and the other half to a negative one. The numbers of items focused on pupil success are: $3,4,5,6,10,14,15,16,18$ and 19 . The items related to pupil failure are: $1,2,7,8,9,11,12,13,17$ and 20 .

Firstly, we will present results related to pupil success indicated in Figures 1-3. Figure 1 shows that $79 \%$ of pre-service teachers attribute the responsibility for pupil success to themselves. As presented in Figure 2, over $90 \%$ of respondents feel responsible for pupil success in four questionnaire items and in one of the items all the respondents attribute the cause of pupil to the teacher. The item with $100 \%$ teacher responsibility attribution (Item No.3) is related to a positive evaluation of teacher's performance by a school director. The second highest value can be found in the item describing a positive feedback from a pupil (Item No. 14). Both instances represent third party approval which may have encouraged the respondents to assume responsibility for positive results. It appears that the feedback from the school director is more authoritative and thus motivated our respondents to choose unanimously the first option and take credit for school success of their pupils. 
Figure 1

Subjective teacher responsibility for pupil success

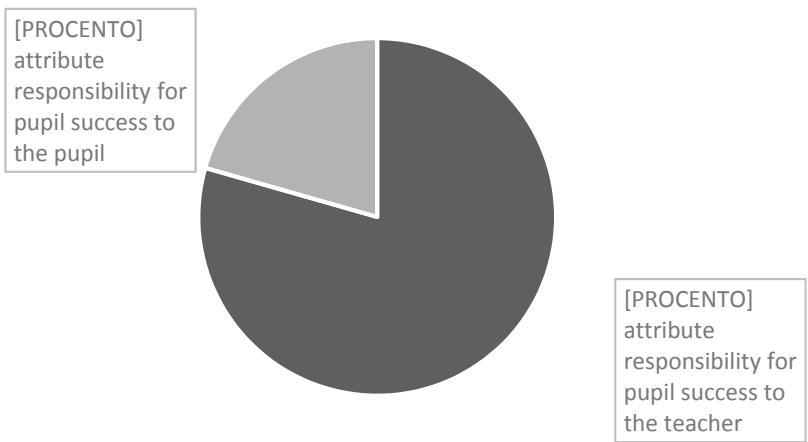

Figure 2

Subjective responsibility for pupil success attributed to the teacher

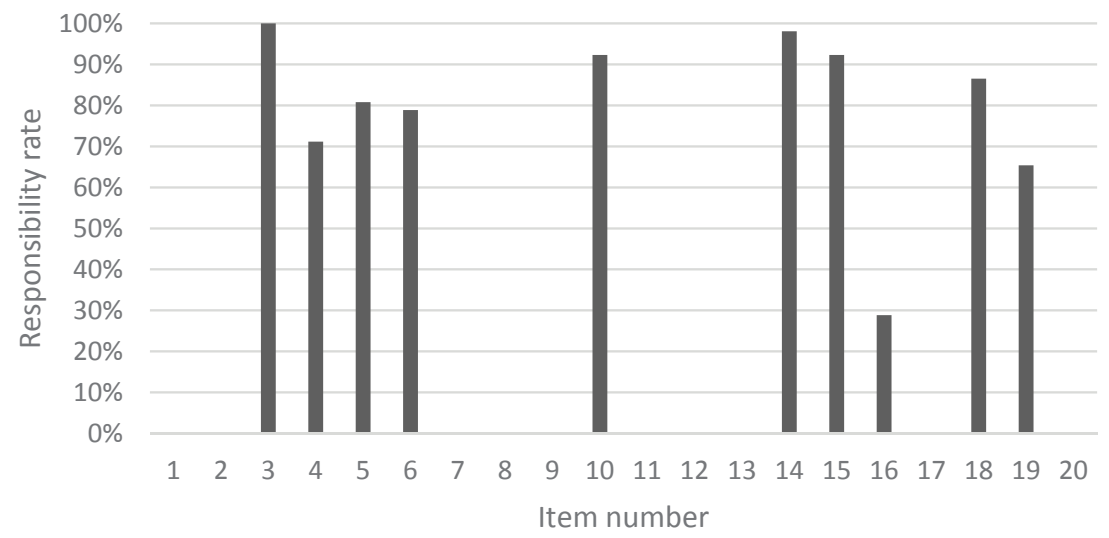

As for the responsibility for success attributed to the pupil, Figure 3 demonstrates that the highest level appears in the situation when a pupil is able to remember a concept after a long time (Item No. 16). In this case over $70 \%$ of respondents view pupil persistence as the cause of his or her achievement. Considering this item is related to pupil motivation, the results of our research confirm conclusions of Daniels et al. (2017), whose survey proved that teacher trainees and in-service teachers feel the least responsible for pupils' motivation. 
Figure 3

Subjective responsibility for pupil success attributed to the pupil

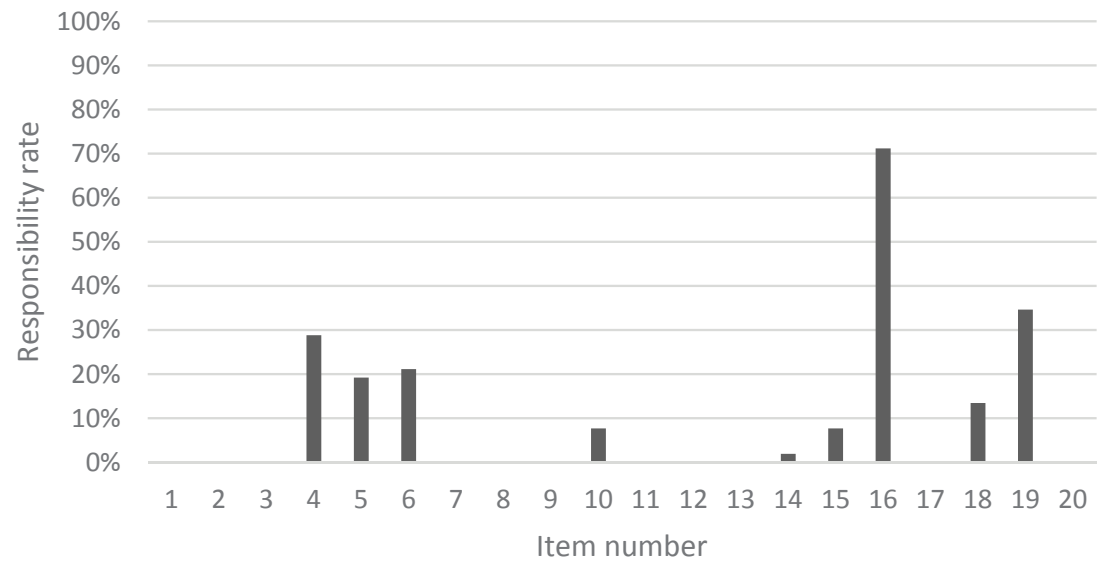

In this part of the section we will comment on the level of subjective responsibility for pupil failure as given in Figures $4-6$. As can be seen in Figure 4 more than half of the respondents attribute responsibility for pupil failure to themselves. The most frequent results given in Figure 5 are near 50\%, which demonstrates a more even distribution of responsibility for pupil failure between teachers and pupils.

The highest value, over 90\%, appears in the first questionnaire item (Item No. 1) describing pupils having difficulty understanding what teacher has explained to them (see Figure 5). On the contrary, as shown in Figure 6, in a situation when a pupil cannot remember something that the teacher has just said (Item No. 2), more than $80 \%$ attribute the cause for his or her failure to pupil's lack of attention. This suggests that the respondents do not feel responsible for attracting their pupils' attention and they do not believe that they can influence it but they feel responsible for an adequate explanation of the lesson content. In other words, they hold themselves responsible for their own teaching. Similarly, in the research of Daniels et al. (2017), teacher trainees and in-service teachers felt the most responsible for their own teaching. This may be accounted for the fact that they consider knowledge transmission a primary goal of the teaching profession. 
Figure 4

Subjective teacher responsibility for pupil failure

\begin{tabular}{|c|}
\hline [PROCENTO] \\
attribute \\
responsibility for \\
pupil failure to \\
the pupil
\end{tabular}

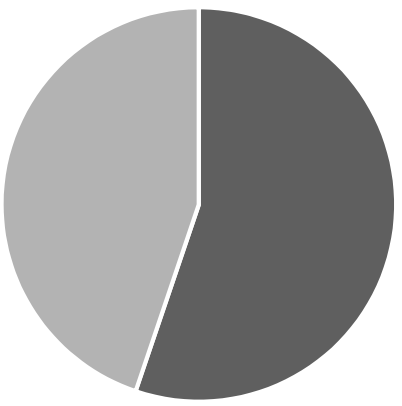

[PROCENTO] attribute responsibility for pupil failure to the teacher

Figure 5

Subjective responsibility for pupil failure attributed to the teacher

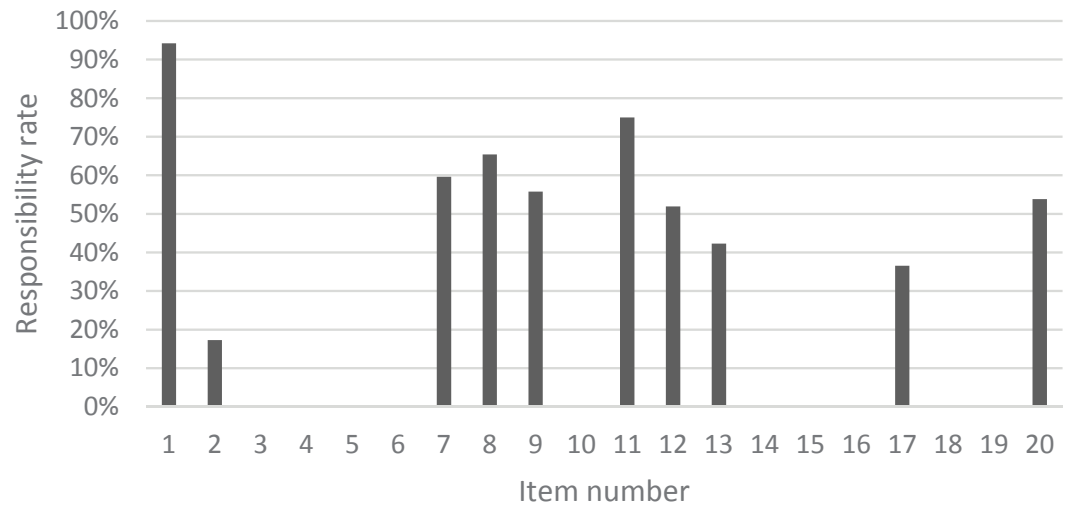


Figure 6

Subjective responsibility for pupil failure attributed to the pupil

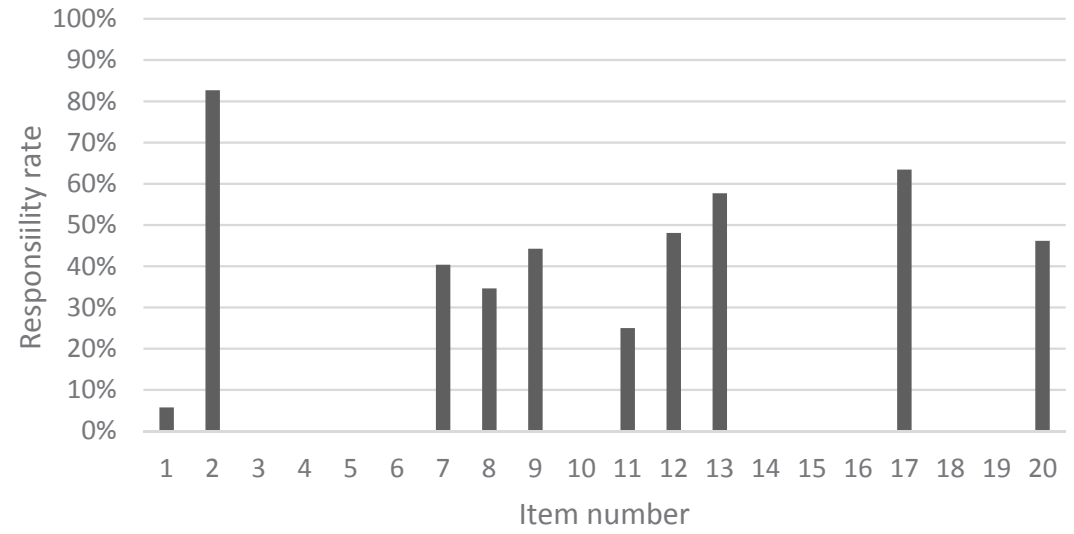

The tendency of pre-service teachers to assume a greater responsibility for pupil success than for pupil failure reflects a general tendency of causal attribution (Weiner, 2008) and has been demonstrated in previous research (Guskey, 1981, Mareš, Skalská, Kantorková, 1994, Frumos, 2015, Dofková, Zdráhal, 2018). However, the results of our survey indicate that the respondents attribute more responsibility to themselves than to the pupils even in case of their failure. This might be due to the applied reflective model of teacher training, which encourages students to develop self-reflective techniques and evaluate their own professional development.

Focus on student trainees' identity is important and research in this area "can help educators to emphasize the multidimensionality and complexity of the teaching profession" (Živković et al., 2018, p. 221). Teacher responsibility is a part of teacher professional identity (Mareš, Skalská, Kantorková, 1994) and it is vital to promote pre-service teachers' responsibility for pupils during their studies (Guskey, 1981, Daniels et al., 2017) because it can make them realize the difference they make in the classroom.

\section{Conclusion}

The objective of this study has been to investigate the level of subjective teacher responsibility for pupil outcomes. Our research addressed only the responsibility attribution view of pre-service teachers with a limited teaching practice. It should also be noted that this study has examined only a relatively small sample size. 
The data analysis demonstrates that pre-service teachers have a rather strong tendency to attribute responsibility for pupil success to themselves, while the level of responsibility attribution for pupil failure to a teacher is significantly lower. However, rather surprisingly, even in the case of failure, more respondents feel responsible for pupil outcome. Despite its preliminary character, the research reported here seems to indicate how pre-service teachers perceive their influence on pupil results and to what extent they tend to attribute responsibility for pupil achievement or failure to pupils. In our future research we will repeat the questionnaire investigation with the same participants for two subsequent years, while in each year students from the first year will be included too.

Unfortunately, we are unable to determine from this data what aspects influence the level of subjective teacher responsibility for learning results. However, we would like to reveal these influential factors in our future research. One possible strategy is to combine the quantitative questionnaire method with a qualitative approach. Semistructured interview to inquire about students' perception of responsibility categories present in the questionnaire might shed light on their understanding of individual items and may help to clarify the levels of subjective teacher responsibility demonstrated in the quantitative research.

\section{Acknowledgements}

This paper is based on research completed as partial fulfilment for the Ph.D. requirements. I would like to thank to my supervisor Professor Hana Lukášová for her invaluable contributions at multiple stages of this research project. I am also grateful to Doctor Miroslava Dolejšová, who provided insight and expertise that greatly assisted the research, especially the data analysis and interpretation of the results. My grateful thanks are also extended to Docent Lengálová for a great help with aspects of writing in Academic English.

\section{References}

Bandura, A. (1991). Social-cognitive theory of self-regulation. Organizational Behavior and Human Decision Processes, 50, 248-287.

Bandura, A. (1994). Self-efficacy. In Ramachaudran, V. S. (ed.) Encyclopedia of human behavior, 4, New York: Academic Press, 71-78.

Daniels, L., M. et al. (2017). Combinations of Personal Responsibility: Differences on Pre-service and Practicing Teacher's Efficacy, Engagement, Classroom Goal Structures and Wellbeing. Frontiers in Psychology, 8, 906. 
Dofková, R., Zdráhal, T. (2018). The responsibility for student's achievement applied to pre-service elementary school math teachers. INTED2018 Proceedings, 1387-1394.

Frumos, L. (2015). Teachers' sense of efficacy and responsibility for students' outcomes. Journal of Innovation in Psychology, Education and Didactics 19(2), 255-262.

Gavora, P. (2008). Učitel'ovo vnímanie svojej profesijnej zdatnosti (self-efficacy). Pedagogika, 58(3), 222-235.

Guskey, T. R. (1981). Measurement of the responsibility teachers assume for academic successes and failures in the classroom. Journal of Teacher Education, 32(3), 44-55.

Helker, K., Wosnitza, M. (2014). Responsibility in the School Context - Development and Validation of a Heuristic Framework. Frontline Learning Research, 5, 115-139.

Lauermann, F., Stuart A. Karabenick, S. A. (2011). Taking Teacher Responsibility Into Account(ability): Explicating Its Multiple Components and Theoretical Status, Educational Psychologist, 46(2), 122-140.

Lauermann, F., \& Karabenick, S. A. (2013). The meaning and measure of teachers'sense of responsibility for educational outcomes. Teaching and Teacher Education, 30, 13-26.

Lukášová, H. (2015). Učitelské sebepojetí a jeho zkoumání. Zlín: Univerzita Tomáše Bati ve Zlíně, Fakulta humanitních studií.

Lukášová, H. (2017). Učitelské sebepojetí - podněty k auto-evaluaci a výzkumu. e-Pedagogium, 17(1). 46-48.

Lukášová-Kantorková, H. (2003). Učitelská profese v primárním vzdělávání a pedagogická příprava učitelů (teorie, výzkum, praxe), Ostrava: Ostravská univerzita v Ostravě, Pedagogická fakulta.

Mareš, J., Skalská, H., Kantorková, H. (1994). Teacher subjective responsibility for pupil school achievement. Pedagogika, 44 (1). Praha: PedF UK, 23-36.

Mareš, J. (2013). Pedagogická psychologie. Praha: Portál.

Matteucci, M.C., Guglielmi, D., Lauermann, F. (2017). Teachers' sense of responsibility for educational outcomes and its associations with teachers' instructional approaches and professional wellbeing. Social Psychology of Education, 20, 257-298.

Matteucci, M. C., Kopp, B. (2013). "Do they feel responsible?" Antecedents of teachers' sense of responsibility. In Proceedings of $5^{\text {th }}$ International Conference on Education and New Learning Technologies. Barcelona, 5013-5017.

Pol, M. (2007). Škola v proměnách. Brno: MU.

Rotter, J. B. (1966). Generalized expectancies for internal versus external control of reinforcement. Psychological Monographs: General and Applied, 80(1), 1-28.

Šatienè, S. (2017). Self-directed learning in later life: motives and learning competences of retired teachers. e-Pedagogium, 17(2), 50-61.

Silverman, S. K. (2010). What Is Diversity? An Inquiry Into Preservice Teacher Beliefs. American Educational Research Journal, 47 (2), 292-329.

Weiner, B. (2008). Reflections on the History of Attribution Theory and Research: People, Personalities, Publications, Problems. Social Psychology, 39 (3), 151-156.

Živković, P. Stojanović, B, Rstanović, D. (2018). Student Teachers' Professional Identity: Research in the Republic of Serbia. The New Educational Review, 51, 221-229.

\section{Contact:}

Mgr. Veronika Pečivová

Faculty of Humanities

Tomas Bata University in Zlín

Štefánikova 5670, 76001 Zlín, Czech Republic

E-mail:vpecivova@utb.cz 


\section{Annex 1}

Questionnaire of pre-service teacher responsibility for pupil outcome

(Mareš, J., Kantorková, H., 1991, In Lukášová-Kantorková, 2003)

1. When your class is having trouble understanding something you have taught it is usually

a) because you did not explain it very clearly

b) because you students are just slow in understanding difficult concepts

2. When a student in your class can't remember something you said just moments before, it is usually

a) because you did not stress the point strongly enough

b) because some students just don't pay attention

3. Suppose your chairman or principal says you are doing a fine job. That is likely to happen

a) because you've been successful with most of your students

b) because chairmen and principals say that sort of things to motivate teachers

4. Suppose you are particularly successful in one class. It would probably happen

a) because you helped them overcome their learning difficulties

b) because these students usually do well in school

5. If your students learn an idea quickly, it is

a) because you were successful in encouraging their learning efforts

b) because your students are basically intelligent

6. When your students seem to learn something easily, it is usually

a) because they were already interested in it

b) because you have helped them organize the concepts

7. When a large percent of the students in your class are doing poorly, it usually happens

a) because they have done poorly before and don't really try

b) because you haven't had the time to give them all the help they need 
8. When students in your class forget something that you explained before, it is usually

a) because most students forget new concepts quickly

b) because you didn't get them actively involved in learning

9. When you find it hard to get a lesson across to particular students, it is
a) because you haven't insisted on their learning earlier lessons
b) because they are just slow in understanding and learning

10. Suppose you present a new idea to your students and most of them remember it. It is likely to be
a) because you reviewed and re-explained the difficult parts
b) because they were interested in it even before you explained it

11. When your students do poorly on a test, it is
a) because based on their previous result, they were not expected to succeed
b) because you didn't insist they prepare adequately

12. If a child doesn't do well in your class, it would probably be

a) because he did not work very hard

b) because you didn't provide the proper motivation for him

13. Suppose you don't have as much success as usual with a particular class. This would happen
a) because you didn't plan as carefully as usual
b) because these students just had less ability than others

14. If one of your students says: "You know, you're a pretty good teacher", it is probably a) because you make learning interesting for students

b) because students generally try to get on a teacher's good side

15. When students in your class remembers something you talked about weeks before, it is usually
a) because some students have that potential to remember things well
b) because you made the point interesting for them

16. If you are working with a student who can't remember a concept and he suddenly gets it, that is likely to happen

a) because you have given him regular feedback on each learning step

b) because he usually works on something until he gets it 
17. When you are having hard time getting your students interested in a lesson, it is usually

a) because you didn't have the time to plan the presentation well

b) because your students are generally hard to motivate

18. When your students seem interested in your lessons right from the beginning, it is

a) because the topic is one which students generally find interesting

b) because you were able to get most of the students involved

19. If you were to discover most of the students in your class are doing very well, it would probably be

a) because their parents were supporting the school's efforts

b) because you had been able to motivate them to work hard

20. When your students seem to have difficulty learning something it is usually a) because they are not willing to really work at it

b) because you weren't able to explain it properly or get them practice it enough

Veronika Pečivová is a lecturer at the Language Centre of the Faculty of Humanities, Tomas Bata University in Zlín, Czech Republic. She teaches English and Spanish language at different TBU faculties. She is also a PhD student at the Department of School Education, Faculty of Humanities, Tomas Bata University in Zlín, Czech Republic. Her research activities focus on teacher subjective responsibility and teacher training. 